\title{
An update on pathological implications of enzymatic dysregulation in Alzheimer's disease.
}

\author{
Amarendranath Choudhury ${ }^{1,2 \# *}$, Indrajeet Chakraborty ${ }^{3 \#}$, Rudrarup Bhattacharjee ${ }^{2}$, Tuhin Subhra \\ Banerjee $^{4}$, Dhilleswara Rao Vana ${ }^{5}$, Dattatreya Adapa ${ }^{6}$, Rajat Bhardwaj ${ }^{7}$ \\ ${ }^{1}$ Independent Researcher, Vizianagaram, Andhra Pradesh, India \\ ${ }^{2}$ Alumnus, Department of Life Science and Bioinformatics, Assam University, Silchar, India \\ ${ }^{3}$ Department of Bioinformatics, Karunya University, Tamil Nadu, India \\ ${ }^{4}$ Satpalsa High School, West Bengal, India \\ ${ }^{5}$ Center for Excellence in Genomics, MKU, Tamil Nadu, India \\ ${ }^{6}$ Department of Microbiology, Food Science and Technology, GITAM Institute of Sciences, GITAM University, \\ Visakhapatnam, Andhra Pradesh, India \\ ${ }^{7}$ Neuropharmacology Division, Department of Pharmacology, ISF College of Pharmacy, Moga, Punjab, India \\ \#These authors equally contributed to this manuscript
}

\begin{abstract}
Alzheimer's Disease (AD) is the most prevalent non-reversible neurodegenerative disorder that affects the memory and cognitive centres of brain. It has been reported that, $\mathrm{AD}$ turns out to be prominent among the people aged $\sim 65$ or above and is regarded as the most common cause of dementia. Moreover, AD stands among the leading causes of death in the first world nations, accounting more than $60 \%$ incidence of progressive cognitive impairment in elderly people. Amyloid beta and neurofibrillary tangles are two putative cytotoxic entities that have been identified, aggregation of which has been associated with the pathological signature of $\mathrm{AD}$. Beta secretases-an amyloid precursor protein cleavage enzyme, plays a pivotal role in such pathogenic process of AD. Several other enzymatic dysregulations have also been linked with $\mathrm{AD}$. Involvement of enzymatic dysregulation is the most discussed pathological implication in AD and therapeutic approaches have been postulated targeting such anomalies. Together, global consequences of enzymatic dysregulation and related therapeutic possibilities in AD remain the prime focus of present time. Therefore, research and study for the eloquent insight into the AD pathology from enzymatic perspective is essential and the same endeavour has been carried out in the present study.
\end{abstract}

Keywords: Alzheimer's disease, Amyloid beta, Beta secretase, Glycogen synthase kinase 3 beta, Acetylcholinesterase, Rho kinase, Prolyl endopeptidase, Monoglycerol lipase, Catechol-O-methyl transferase.

Accepted on June 25, 2018

\section{Introduction}

Alzheimer's Disease (AD) — an age-related, insidious neurodegenerative disorder, characterised by cognitive and memory impairment. It has been reported that $\mathrm{AD}$ is frequent among people with an age group of 65 or more. Clinically, AD is the common cause of dementia and regarded as the most common cause of death in the first world nations [1]. Over $60 \%-70 \%$ incidents of cognitive impairment in elderly patients have been found to be associated with $\mathrm{AD}$ [2]. The overall prevalence of $\mathrm{AD}$ in USA alone is around 2.3 million as per the statistics made in the early $20^{\text {th }}$ century [3]. The prevalence of $\mathrm{AD}$ among men $v s$. women is observed in the ratio of $1: 2$ to 1:5 [4]. Two known forms of AD have been reported; namely, familial and sporadic variety. Familial AD is less prevalent and stands around $10 \%$ of the total $\mathrm{AD}$ patient population [5]. Regardless the variety of $\mathrm{AD}$, medical care becomes excessively necessary in the final phases of $\mathrm{AD}$ i.e., the last three years before death due to the reason that, $\mathrm{AD}$ not only causes memory loss but also incorporates the symptoms like dramatic personality changes, lack of physical coordination, and disorientation [6]. Generally, the final stages of $\mathrm{AD}$ are even more dramatic where victims are bedridden, with loss of 
control in urinary and bowel movement, and frequent epileptic attacks [7]. Clinically, loss of synaptic function, presence of amyloid plaque, neuro-fibrillary tangles (NFT) and brain atrophy in specific brain areas confirm the presence of AD [8]. In a living patient, dementia is hard to confirm accurately; however, near to accurate diagnosis is possible through cognitive tests such as delayed recall and exclusion of other conditions such as hypothyroidism, nutritional deficiency and stroke [9]. An effective therapy for dementia is yet to be discovered. Safety concerns over synthetic drugs are now being promoted and drugs based on natural origin, are trending globally.

Enzymatic dysregulation is the most common pathological scenario of $\mathrm{AD}$ and involvement of such dysregulation has been targeted in several therapeutic approaches for AD [10]. Beta-secretase ( $\beta$-secretase) is considered as the most critical enzyme involved in the AD pathology. Amyloid precursor protein (APP) is the substrate for $\beta$-secretase and uncontrolled cleavage of APP generates amyloid beta $(A \beta)$ [11]. A $\beta$ oligomers are aggregation prone, which in advanced stage forms toxic senile plaques both in cytosol and extracellular matrix. Another crucial enzyme is glycogen synthase kinase-3 $\beta$ (GSK-3 $\beta$ ), which is having pathogenic role by assisting in the process of tau-protein hyperphosphorylation. Hyperphosphorylated tau is also having the tendency to aggregate and it has been identified as an ingredient of toxic senile plaques [12]. Moreover, hyperphosphorylated tau protein is known to modify other essential protein structures by phosphorylation and GSK-3 $\beta$ plays determining role in such cases. Enzymes like acetylcholinesterase; Rho kinase; prolyl endopeptidase; monoglycerol lipase; catechol-O-methyl transferase, are also having a putative role in the pathogenesis of $\mathrm{AD}$ [13]. Pathogenic role of each enzyme has been discussed in the present study for the better understanding of $\mathrm{AD}$ pathology. It is notable that several synthetic and herbal therapeutic approaches have been postulated, where regulation of such enzymatic function is the centre of remedy [14]. Though, complete cure of AD is still unaccomplished.

Global research in search of therapeutic values of various plant species is going on and few plants have been identified with potential efficacy to improve symptomatic AD pathology [14]. Countless mentions from ayurvedic medicinal recipe also have offered better therapeutic promises [15]. Another advantage of herbal therapy is that, it contains no or less side effects and is available at a very low cost [16]. Since immortal time of mankind, traditional medicines served as potential therapeutic means against mental disorders and success of such approach has gained immense interest and popularity across the globe [17]. Together, enzymatic dysregulation is the crucial point of interest for therapeutic intervention against AD.

\section{Overview of AD}

$\mathrm{AD}$ is the most common neurodegenerative disorder and also the main cause for dementia in humans. Initial symptom of AD includes short term memory loss that develops into profound memory failures at subsequent stages [18]. AD is having two distinct pathological signatures namely senile plaques (containing deposits of $\mathrm{A} \beta$ protein) and NFT; consisting of hyperphosphorylated tau protein. In the early stages of disease, huge number of neuronal cells dies causing neuronal losses in the brain's memory regions. Studies in this regard, showed that aberrant proteolytic processing of the APP leads to A $\beta 1-40$ and A $\beta 1-42$ fragments capable of initiating cytotoxicity in neuronal environment in AD brain [19]. Nonetheless, the knowledge concerning mechanism behind plaque deposition, neuronal cell death, and NFT by A $\beta$ proteins still remains unclear.

\section{Incidence and Prevalence of AD}

More than four million people in the United States are presently affected by AD. It is now causing more number of deaths compared to those caused due to stroke. Together, stroke and AD stand as the third most common cause of deaths in USA [20]. Statistically, the prevalence of $\mathrm{AD}$ is found to be more common among women. As per the data published in Diagnostic and Statistical Manual of Mental Disorders $\left(4^{\text {th }}\right.$ Edn.), prevalence of dementia is observed in the range of $1 \%$ in developing countries like India, Peru, etc. to almost $6.4 \%$ in countries like Cuba. As compared to developed countries, developing countries like India, Nepal, Brazil, Nigeria, and Taiwan show lower annual incidence estimates in the range $1 \%-2 \%$ of total reported cases [21-24]. Mean survival time for $\mathrm{AD}$ patients in developed countries is perceived to be 5 y to 9.3 $\mathrm{y}$ while that in developing countries, it is $3.3 \mathrm{y}$ from the time dementia sets in. For AD patients, the mean survival time further reduces to meagre $2.7 \mathrm{y}[23]$.

\section{AD Pathology}

Amyloid beta peptides (A $\beta)$ production and clearance determines molecular pathogenesis of AD. Primarily, generation of A $\beta$ occurs through cleavage of APP by beta- and gamma- processing enzymes. These are then cleared from the brain through diffusion, exported to vascular system, and followed by degradation or phagocytosis [25]. Experimental studies in this regard have provided some insights into the molecular mechanism of AD; identifying APP as the causative gene for Familial AD (FAD). In a mouse-based animal model, endogenous apolipoprotein E4 (APOE-4) was observed to enhance $A \beta$ deposition [26,27]. Presence of aggregates of hyperphosphorylated tau proteins commonly referred to as NFT serves as the primary markers for diagnosis of AD. These insoluble NFT have an abnormal conformation and are deposited in the neuronal cell bodies. These are capable of forming specific insoluble structures called paired helical filaments (PHF) [28,29]. Alternate splicing of tau gene gives rise to six tau protein isoforms; primarily used for stabilization and binding of microtubules thereby promoting microtubule polymerization. The mechanism behind aggregation or PHF formation is attributed to hyperphosphorylation of tau which induces disassociation of tau from microtubules [30,31]. 


\section{Role of Oxidative Stress in AD}

On account of high lipid content, brain is prone to oxidative damage. In addition to this, high rate of metabolic function and supply of the required transition metals makes it an easy target for free radical attacks [32]. Direct evidences in this regard are, increased composition of $\mathrm{Fe}, \mathrm{Al}$, and $\mathrm{Hg}$ in the brain, reduction in levels of polyunsaturated fatty acids in the brain, increased lipid peroxidation as well as rise in levels of ventricular fluids such as 4-hydroxynonenal which is produced in the process, increased DNA and protein oxidation in the brain, decreased cytochrome $\mathrm{c}$ oxidase in the brain along with diminished energy metabolism [33], advanced glycation end products (AGE), malondialdehyde, carbonyls, peroxynitrite, heme oxygenase-1 and superoxide dismutase-1 (SOD-1) in NFT and AGE, heme oxygenase-1, SOD-1 in senile plaques, and generation of free radicals by $\mathrm{A} \beta$.

Oxidative stress induces serious damage to formation of biological macromolecules like malondialdehyde and lipofusin [34]. As per experimental studies, oxidative damage primarily involves lesion on account of low protein outputs [35]. In lesions of $\mathrm{AD}$, adduction production of hydroxynomenal [36] and acrolein [37] is also found due to lipid peroxidation. Nevertheless, lesions are not the dominant sites of damage, rather neuronal cytoplasm of neurons are susceptible damage sites of death and damage in AD. Inside the cell, cross linked products of lipid peroxidation and glycation undergo oxidative modification thus, becoming more and more resistant to breakdown. Crosslinking not only hinders proteasome activity [38] but also renders proteins resistant to removal by proteasomes. Neurons that face oxidative damage begin to have protein-based reactive carbonyl and nitro tyrosine in the cytoplasm. Evidences of its formation in amyloid $\beta$ or $\tau$ deposits suggest cytoplasm rather than lesions as the source of reactive oxygen species (ROS) [39]. Among vulnerable neuronal populations, 8 -Hydroxyguanosine $(8-\mathrm{OHG})$ a nucleic acid modification obtained through hydroxyl free radical attack on guanidine is greatly increased in the cytoplasmic RNA [40]. 8-OHG decoration was observed more in the endoplasmic reticulum with majority of mitochondria showing scarce 8OHG.

\section{Role of Inflammation in AD}

Pathophysiology of AD involves extensive neuronal death accompanied by deposition of amyloid in various regions of the brain. These amyloid deposits lead to accumulation of several proteins along with underlying inflammatory reactions, thereby resulting in extracellular senile plaques [41]. Intracellular deposition of hyperphosphorylated degenerate filaments results in NFT that form due to the aggregation of micro tubular protein tau. Such cellular progresses results in heavy amounts of neuronal losses in the hippocampus, entorhinal cortex, and associated regions of brain neocortex. Although, the reason behind neuronal cell death still remains unknown yet postulates in this context suggest 'apoptosis' as a possible reason [42]. Inflammation is also seen to be actively involved in the progression and pathology of AD. Association of microglia with the senile plaque leads to amyloid plaque deposition which results in the phenotypic activation and subsequent elaboration of neurotoxic as well as proinflammatory factors [43].

Neurons which are located nearby chronically activated astrocytes and microglial cells die out due to toxins such as ROS intermediates, proteolytic enzymes, excitatory amino acids, nitric oxide, complimentary factors etc. Proinflammatory cytokines not only enhances $\mathrm{A} \beta 40$ and $\mathrm{A} \beta 42$ peptide production but also decreases APP solubility alongside providing neuroprotective effects [44]. In the onset of a neurological disease, APP modification begins long before disease symptoms begin to appear. During disease period, astrocyte and microglial cells activate following binding of $A \beta$ to the CD14 receptor and its co-receptor-toll-like receptor 4 (TLR4). After which morphological changes in microglial cells is observed, these now turn into tissue macrophages producing inflammatory molecules [45]. This has generated enormous interest towards the in vitro study of the anti-inflammatory effect of selected plant extracts.

\section{Enzyme Involved in AD Pathobiology}

\section{Beta secretase}

A large type-I membrane protein called APP, when gets endoproteolysed, it generates the $A \beta$ peptide $[46,47] . A \beta$ is a normal catabolic product of APP metabolism in cells showing ubiquitous expression of APP. APP cleavage by $\beta$-secretase form the amino terminus Asp +1 residue of the $A \beta$ sequence. This process generates two cleavage products, viz., a secreted ectodomain of APP, named APPs $\beta$ and second being the C99 fragment, the membrane-bound C-terminal 99 amino acids residue (Figure 1) [48]. After the first cleavage, the C99 get acted upon by a second protease called $\gamma$-secretase. This enzyme cleaves C99 to generate the carboxyl terminus of $A \beta$ along with a mature peptide which is then secreted from the cell. The non-precise $\gamma$-secretase cleavage results in a spectrum of $A \beta$ peptides that vary in length by a few amino acids at the carboxyl terminus, however, majority of $\mathrm{A} \beta$ terminates at $40^{\text {th }}$ amino acid residue. Another type of protease called $\alpha$ secretase, cleaves APP in the mid-A $\beta$ domain (at Leu+17) and hence, precludes the formation of $A \beta$ [49]. The $\alpha$-secretase produces two cleavage products: the secreted APPs $\alpha$ ectodomain and the membrane-bound $\mathrm{C}$-terminal fragment C83. The C83 is then cleaved by $\gamma$-secretase to form a $3 \mathrm{kDa}$ fragment, p3 [50]. Intriguingly, the APP mutations leading to FAD occur at APP near the site of cleavage and as a result, the mutations directly affect cleavage efficacy. For example, the Swedish mutation is the amino acid substitution of lysine and methionine to asparagine and leucine at the P2-P1 positions at $\mathrm{N}$-terminal of the $\beta$-secretase cleavage site in APP [51]. This double mutation makes APP a much better substrate for $\beta$ secretase thus dramatically increasing the cleavage efficacy. Many more examples of FAD mutations have been identified that are positioned near the $\gamma$-secretase cleavage site and these shift the balance of $\gamma$-secretase cleavage towards generation of 
the more toxic $\mathrm{A} \beta 42$ (similar to the action of FAD mutations in the presenilins) [52]. Moreover, efficiency of $\alpha$-secretase cleavage has been reduced by mutations in FAD near the enzyme cleavage site. This alteration results in furnishing more APP as substrate for $\beta$-secretase cleavage and consequent generation of $\mathrm{A} \beta$.

Establishment of the fact that APP endoproteolysis produces $\mathrm{A} \beta[53,54]$, resulted in information hunt on the properties of $\beta$ secretase activity in cells and tissues. Concommitant studies utilized the data in various ways to validate certain $\beta$-secretase 1 (BACE-1) attributes. In this context, $\beta$-secretase activity has been briefly reviewed. This enzyme has been detected in majority of the body cells and tissues [55], but its maximum activity has been found in neural tissue and neuronal cell lines [56]. One interesting fact is expression of $\beta$-secretase activity in astrocytes is less compared to neurons [57]. The research reports strongly indicated that $\beta$-secretase might be widely expressed in many tissues and cell lines but its maximum expression is found in neurons of the brain. $\beta$-secretase activity in cells results in efficient cleavage of membrane-bound APP only, whereas APP constructs lacking the transmembrane domain did not get cleaved when transfected into cells [58]. The fact implied that $\beta$-secretase might be a membrane-bound protease or, alternatively, it is strongly associated with a membrane protein for its function. At an acidic $\mathrm{pH}, \beta$-secretase shows maximum activity and hence, the agents that disrupt intracellular $\mathrm{pH}$ also inhibit $\beta$-secretase activity $[59,60]$. Additionally, cellular level studies found maximum $\beta$-secretase activity in the acidic subcellular compartments of the secretary pathway, including the Golgi apparatus and endosomes $[61,62]$. From these results, it has been postulated that the active site of $\beta$-secretase might be situated within the lumen of acidic intracellular compartments. Amino acids surrounding the cleavage site in APP when changed by site directed mutagenesis leads to identification of sequence preferences of $\beta$-secretase [63]. Substitution of larger hydrophobic amino acids (such as Leu found in the Swedish FAD mutation) for the Met residue at P1 site improved $\beta$-secretase cleavage efficiency. Conversely, substitution of the smaller hydrophobic amino acid Val at the same position showed cleavage inhibitory effect. Some more substitution studies at this site and at some surrounding positions showed a decrease in cleavage efficacy and hence establish the fact that $\beta$-secretase is highly sequence specific. Studies from radiosequencing demonstrates that $\mathrm{A} \beta$ isolated from amyloid plaques and those produced in cell lines, predominantly begins at the Asp +1 residue of $A \beta$ [64]. But, some $A \beta$ species were found to begin at Val-3, Ile-6, and Glu+11 residues also [65]. Studies utilizing inhibitors suggest that the Val-3 and Ile- 6 species are generated by a protease other than $\beta$-secretase [66]. However, the Glu+11 species is found to be produced in parallel with Asp $+1 \mathrm{~A} \beta$ which suggests that $\beta$-secretase can cleave at both positions. Interestingly, the Glu+11 species is found to be the predominant form of $A \beta$ made in rat primary neuron cultures [67]. Finally, $\beta$-secretase shows no sensitivity towards pepstatin which is an inhibitor of many (but not all) aspartic proteases.

\section{Glycogen synthase kinase $3 \beta$}

Glycogen synthase kinase $3 \beta$ (GSK3 $\beta$ ) has been linked as a central player in AD by many studies. It has been found that deregulation of GSK3 $\beta$ shows numerous pathological hallmarks of the disease in both sporadic and FAD cases [68]. These crucial findings led to ultimate formulation of the 'GSK3 $\beta$ hypothesis of AD'. Evidences from studies showed that GSK3 $\beta$ is intimately involved in the hyperphosphorylation of tau, memory impairment, increased production of $A \beta$ and also in inflammatory responses (Figure 1). GSK $3 \beta$ has reductive effect in acetylcholine synthesis, which is in accordance with the cholinergic deficit character of $\mathrm{AD}$ [69]. Moreover, GSK3 $\beta$ is a key mediator of apoptosis and hence involves the possibility to contribute towards neuronal cell death in $\mathrm{AD}[70]$.

Naturally if GSK3 $\beta$ is central to AD pathogenesis, its increased activity in $\mathrm{AD}$ patients should be a common occurrence. However, there is little such evidence, as it is technically difficult, if not impossible, to measure enzymatic activity in post-mortem brain tissue. Certain indirect evidences from many studies do support the role of GSK $3 \beta$ in disease and it shows co-localization with dystrophic neurites and NFTs [71-73]. Active GSK3 $\beta$ appears in neurons with pre-tangle changes [74] and in AD pathology, there is increased GSK3 $\beta$ activity in the frontal cortex which was evidenced by immunoblotting for GSK3 $\beta$ phosphorylated at Tyr216 [75]. Furthermore, the hippocampus region of AD patients shows up-regulated GSK3 $\beta$ expression [76]. In case of both AD and mild cognitive impairment, GSK3 $\beta$ expression is up-regulated in circulating peripheral lymphocytes [77]. It has recently been reported that a polymorphism in the GSK $3 \beta$ promoter is a risk factor for late onset $\mathrm{AD}$ [78] and the same might account for alterations in GSK3 $\beta$ expression in disease. Collectively, these findings suggest that GSK3 $\beta$ activity might be increased in AD and the process changes in phosphorylation state as well as in expression levels. But still direct evidence for this mechanism is equivocal and some studies have found no change in GSK3 $\beta$ activity [79] or even reduced GSK3 $\beta$ activity in AD [80].

Genetic and epidemiological studies indicate that GSK3 $\beta$ deregulation in $\mathrm{AD}$ is due to alterations in upstream Wnt and insulin signalling pathway intermediates. The low-density lipoprotein receptor related protein 6 (LRP6), a co-receptor for Wnt signaling, has recently been identified as a gene of risk for late onset $\mathrm{AD}$ in apolipoprotein E4-e4 negative individuals [81], implicating aberrant Wnt signalling in AD pathology. In addition, an association of $\mathrm{AD}$ with diabetes and insulin resistance has been reported [82] and genetic studies find insulin signalling genes to be potential target loci for $\mathrm{AD}$ $[83,84]$. As studies suggested, the positive association of Wnt pathway with $\mathrm{AD}$ may help in studying neurological alterations during carcinogenesis or conversely pre-AD stage neuronal alterations, which may be served as a marker for ongoing and future onco-events. 


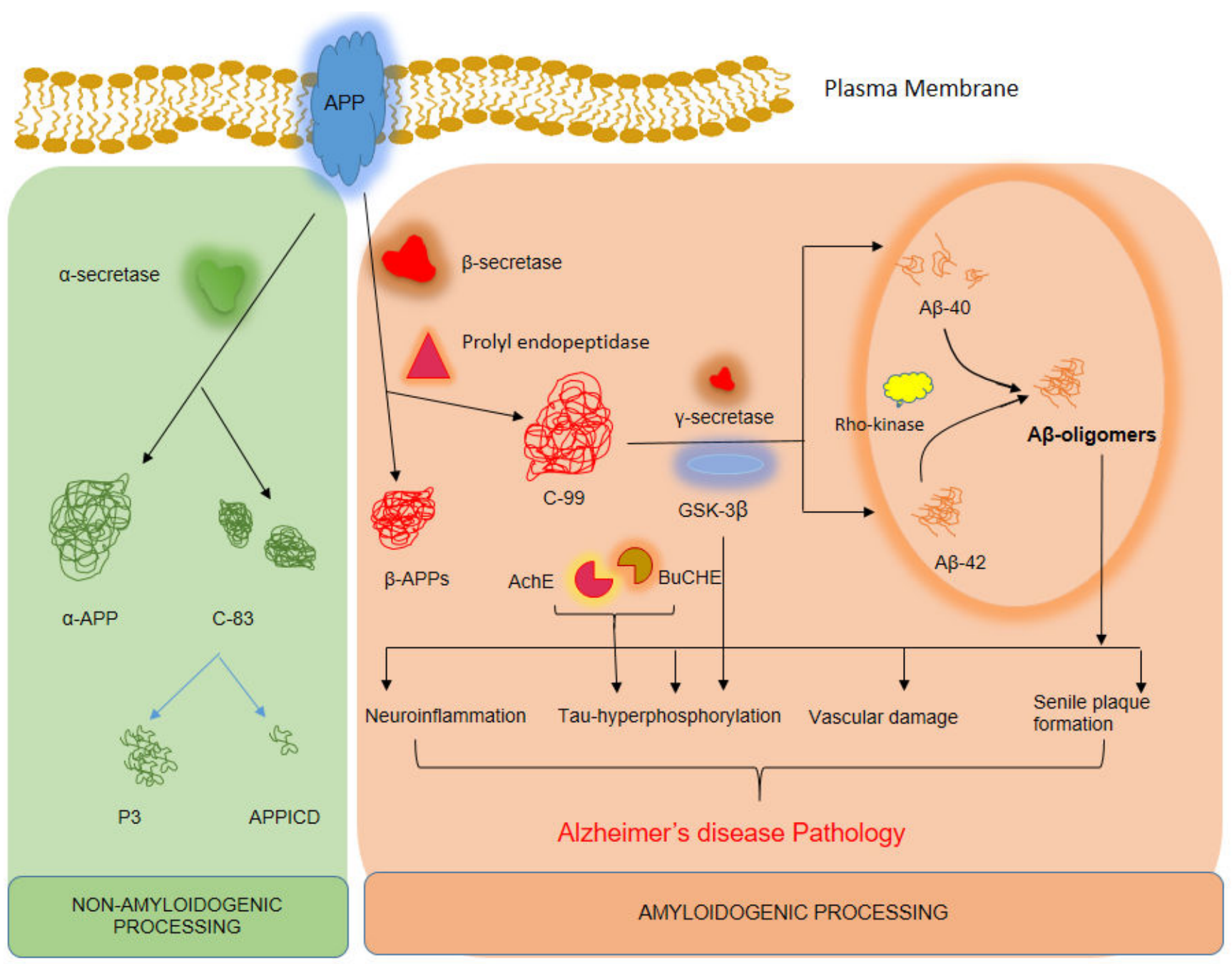

Figure 1. Schematic presentation of enzymes involved in amyloidogenic and non-amyloidogenic processing of APP.

\section{Acetylcholinesterase (AChE) and butrylcholinesterase (BuChE)}

Cholinergic transmission in the central and peripheral nervous system is controlled by a neurotransmitter-Acetylcholine (ACh). ACh hydrolysis is catalysed by Acetylcholinesterase (AChE). Butyrylcholinesterase (BuChE) is another similar group of neurotransmitter which is present in selected areas of central and peripheral nervous system. The cognitive impairment faced by $\mathrm{AD}$ patients is associated with accumulation of NFT, loss of cholinergic functions along with constitution of hyperphosphorylated Tau protein. Both of these enzymes participate in collaboration with plaques, and tangles in $\mathrm{AD}$ [85]. In AD subjects, levels of $\mathrm{AChE}$ and BuCHE are found to be elevated in various regions of the brain. Severity of $\mathrm{AD}$ is expressed in terms of higher activity of AChE and BuChE enzymes along with increased number of cortical and neocortical amyloid rich tangles and plaques [86]. Neuronal losses in AD patients' especially in terms of cholinergic neurons; are associated with apoptotic cell death thereby inducing cortical shrinkage in the brain. The cholinergic neurons are responsible for maximum expression of $\mathrm{AChE}$ as compared to remaining neuronal cells [87]. Prolonged availability of AChE in the neuronal cells serves in amelioration of AD symptoms [88]. Contemporary works suggest that inhibition of $\mathrm{AChE}$ and $\mathrm{BuChE}$ enhances cholinergic transmission in AD. Therefore, current therapeutics involves inhibition of these enzymes with the help of phytochemicals viz. galanthamine, rivastigmine, and donepezil.

\section{Rho kinase}

Rho kinase is a serine or threonine kinase which is activated by binding to active GTP-bound from Rho. Two known isoforms, ROCK II (ROK $\alpha /$ Rho kinase $\alpha$ ) and ROCK I (Rho kinase $\beta /$ ROK $\beta$ ) are existent which phosphorylates various substrates such as myosin-binding subunit (MSB) of myosin phosphatase and myosin light chain (MCL) [89]. ROCK I is expressed abundantly in non-neuronal tissues such as the stomach, liver, and kidney. Whilst ROCK II is preferentially expressed in the brain and muscle tissues. Several functions of the central nervous system (CNS), for instance, regulation of axonal growth [89], formation of branched dendrites [90], long-term spatial memory [91], regulation of the level of amylodogenic A 
$\beta 42$ [92], neurotransmitter release [93], etc. is attributed to Rho/Rho-kinase signalling. In both vertebrates and invertebrates, morphological changes in neurons such as change in dendritic length, size, shape and number of synapses are perceived as hallmarks of long-term memory [89]. Neuronal morphology is controlled by actin filaments and its regulation influences memory. Subsequently, Rho-ROCK pathway is an attractive target of interest for drug discovery works in CNS related disorders. It is recently found that ROCK pathway is closely related to the pathogenesis of several CNS disorders like stroke, AD, spinal cord issues, etc. Poor regeneration of injured axons in adults is observed which is attributed to the presence of myelin-associated growth inhibitors for example Nogo, oligodendrocyte-myelin glycoprotein (OMgp), repulsive guidance molecule (RGM), and myelin-associated glycoprotein (MAG). It is believed that the blockade of Rho-ROCK pathway promotes axonal regeneration and functional recovery of injured $\mathrm{CNS}$ which might further help in reversing the effects of these inhibitors. The Rho-ROCK pathway is also an important regulator of cell growth, apoptosis, and migration via regulation of actin cytoskeleton assembly [89,92]. Reduced cholesterol dependent and independent mechanisms mediate inhibition of antibody production by statins. Even though precise molecular mechanism behind reduction of $\mathrm{A} \beta$ by statins is yet undetermined, it is believed to be associated with enhancement of $\alpha$-secretase activity. Irrespective of depletion in cellular cholesterol levels, statins inhibit small GTPases such as Rho by lowering protein isoprenylation via reduction of mevalonate synthesis [94]. Statin-mediated inhibition of Rho-ROCK results in either the activation of $\alpha$-secretase cleavage [95] or enhancement in APP lysosomal degradation [96], both of which ultimately result in inhibition of $A \beta$ production. Contemporary works report inhibition of neurite outgrowth by $\mathrm{A} \beta$ which is caused through the activation of the Rho-ROCK pathway in H-SY5Y neuroblastoma cells [97]. Inhibitory effects of $A \beta$ is mediated partly through induction of an alternatively spliced form of collapsin response mediator protein-2 (CRMP-2) i.e. CRMP-2A and partly by the upregulated phosphorylation of CRMP-2 by ROCK. Such findings suggest that Rho-ROCK pathway is not only involved in $A \beta$ production but also in $A \beta$ induced neurite outgrowth inhibition. This advocates the beneficiary possibilities of RhoROCK blockers in AD treatment.

\section{Prolyl endopeptidase}

Prolyl endopeptidase (PEP) is a serine protease enzyme known to cleave peptide substrates at the C-terminal end of proline residues. PEP is actively involved in the metabolism of neuropeptides containing proline such as arginine vasopressin, thyrotropin-releasing hormone, substance $\mathrm{P}$ which controls learning and memory process [98-100]. It is found widely distributed among various organs, particularly in the brain of patients with amnestic disorders. Post-mortem analysis of an AD patient's brain reveals significantly increased PEP activity which suggests PEP inhibitor might serve useful as a therapeutic target for an anti-amnestic drug. As per recent findings, involvement of prolyl endopeptidase-a cytosolic enzyme belonging to a distinct class of serine peptidase in processing of C-terminal region of APP has been found in AD subjects. PEP activity in AD subjects is found to be higher as compared to that of a healthy person [101]. Reports also suggest that prevention of memory loss and enhanced attention span in subjects suffering from senile dementia can be prohibited through specific PEP inhibition. This was also reported in scopolamine-treated and dorsal hippocampallesioned rats where memory and learning capability was found to improve [102]. The memory enhancing effects of PEP inhibitor (JTP-4819) is attributed to inhibition of metabolic degradation of brain neuro-peptides by PEP other than enhancement of ACh release. In addition, release of ACh from specific brain regions such as frontal cortex, hippocampus, and regions closely associated with memory is observed as well. Study of PEP inhibitory activity in phytochemicals has therefore turned into a necessity.

\section{Monoglycerol lipase}

Monoglycerol lipase (MGL) is a serine hydrolase which converts monoglycerides into fatty acid and glycerol thereby participating in 2-Arachidonoylglycerol (2-AG) inactivation [103]. Likewise, in case of pathologies like neuroinflammation, pain modulation, and neuro-protection; endocanabinoids system has been postulated as the most suitable target [104]. $\mathrm{CB} 1$ and $\mathrm{CB} 2$ receptors are endogenous endocannabinoid (EC) which along with ligands anandamide (AEA), 2arachidonylethanolamide, degradation causing enzyme like fatty acid amide hydrolase (FAAH), and monoglyceride lipase (MGL) serve as key elements of the EC system [104]. These are useful in a number of physiological functions such as immune response, cognitive activity, and motor function. In the event of a neurological disorder such as $\mathrm{AD}$, Huntington's disease (HD), multiple sclerosis (MS), etc., study of the neuroprotective roles of EC systems as well as the modulations observed in neurotransmission are studied with equal emphasis [87]. It has been observed in various experimental AD models that EC system faces imbalance in terms of decreased neuronal cannabinoid CB1 receptors, increased glial cannabinoid CB2 receptors, and over-expression of FAAH in astrocytes. Postmortem report of $\mathrm{AD}$ brain and $\mathrm{AD}$ animal models have clearly suggested a protective efficacy of EC system [105].

\section{Catechol-O-methyl transferase}

Catechol-O-methyl transferase (COMT) affects levels of catecholamines viz. dopamine, epinephrine, and norepinephrine by degradation. It is mediated through dopamine signalling in the frontal lobes which is the cause of cognitive impairment [106]. COMT is also a suggested candidate for Alzheimerrelated psychosis (AD-P) susceptibility as well as a functional association between valine and methionine polymorphism [106]. Neurotropic factors, like nerve growth factor (NGF), neurotropin 3 (NT-3) or brain derived neurotropic factor (BDNF) promote neuron functioning in the peripheral and central nervous system. These are synthesized in the glial and 
neuronal cells induced by dopamine and other biogenic amines. Clinical studies have helped to understand the role of monoamine oxidase B (MAO-B) inhibitors which slows down the progression of neurological and cognitive deficits in $\mathrm{PD}$ and $\mathrm{AD}$ [107]. An increase in biosynthesis of neurotropic factors mentioned herein is noted upon inhibition of activity for the extra-neuronal and neuronal located monoamine oxidase (MAO) enzyme and/or the predominantly glial situated COMT.

\section{AD and Therapeutic Approaches}

Over the years, traditional medicines especially those of herbal origin have gained tremendous popularity in AD treatment. At present, extensive research on different plants species is underway globally [108]. Economic viability, higher therapeutic window, along with no or less side effects has helped herbal medicines gain acceptance and fame worldwide [109]. Plants like St John's wort, Kava-kava, Valerian, Bacopa monnieri, and Convolvulus pluricaulis are among the ones most studied for their effectiveness in the treatment of neurological disorders [110]. Plant studies for AChE activity include Withania somnifera, Semecarpus anacardium, Embelia ribes, Tinospora cordifolia, Ficus religiosa, and Nardostachys jatamansi [111]. Experimental studies confirm the usefulness of plant extract of Ginkgo biloba in early stages of AD. In the early stages of $\mathrm{AD}$, it helps patients live a reasonably sound life. In the same direction, works conducted by Selkoe et al. confirm that Ginkgo biloba extract has normalising effects on the ACh receptors found at the severely affected hippocampus region of the brain, particularly for older subjects [112]. Selective and competitive inhibition of ACh is also possible with the help of galantamine enzyme. Trails conducted by researchers have emphasised on the significant improvement in disease symptoms of $\mathrm{AD}$ and dementia as observed upon treatment with huperzine A [113,114]. Similarly; strong evidences concerning cognitive function improvement, reduced agitation, and related therapeutic activity is shown by Melissa officinalis (also called as 'lemon balm') which shows both nicotinic and muscarinic binding properties in the CNS $[115,116]$.

As of now, treatment of AD involves drugs which slow down its progression thereby improving the patient's cognitive functions. The pharmaceutical industry at present offers 'memantine' as the only available drug approved for the treatment of mild to severe AD symptoms. It interferes with the functioning of hippocampal neurons by controlling glutamatergic excitotoxicity [117]. Other drugs available are rivastigmine, galantamine, tacrine, and donepezil. Mechanism of action comprises modulation of brain ACh levels through anti-cholinestrase inhibition. Treatment with anti-inflammatory drugs like prednisone [118], diclofenac [119], rofecoxib [120], and naproxen [121,122] show side effects which is presently the major drawback in AD treatment. Side effects include nausea and vomiting. Hepatotoxicity was detected especially in case of treatment with tacrine, therefore it is rarely used. Donepezil, when given once a day is easily tolerated along with improving mental capabilities in AD patients. Similarly, rivastigmine works well when given twice a day.

\section{Conclusion}

The lack of adequate knowledge on the molecular mechanisms of $\mathrm{AD}$ pathogenesis remains a leading cause underlying inadequate treatment and mortality. Progressive research has significantly identified some of the crucial developments of AD pathology; however, the molecular mechanisms, enzymatic actions, signaling pathways involved in AD pathogenesis are not eloquently established. Hence, finding potential biomarkers, drug targets, development of drugs and novel delivery systems is a major challenge. Many studies showed positive and satisfactory outcomes with the usage of herbal medicine and antioxidants but the clinical effectiveness and scope of progression in research are limited due to various factors associated with traditional and herbal medicine. This indicates the need of early diagnostic modalities, potential biomarker identification and designing novel inhibitors or drugs.

The on-going researches in the fields of molecular biology and biomedical engineering are attempting to unfold the underlying molecular events and to explore the mechanistic link between enzymes and $\mathrm{AD}$ pathogenesis. It is believed that, in $\mathrm{AD}$ pathogenesis amyloid-degrading enzymes play a significant role in enzymatic pathway and serve in $A \beta$ clearance. Among the number of enzymes involved, it is very crucial and important to know which of these enzyme(s) are critical and can be served as potential drug targets and easy to regulate. Considering the fact that AD pathology develops over many years, therefore, the early manipulation of these enzymes is essential as it could reduce the disease progression. Identifying the link between AD and other pathological events is important in finding targets. In addition, development of modifiers of AD may also serve as therapeutics for AD. Pharmacological approaches are also important to provide economical treatment options for $\mathrm{AD}$; in addition, development of effective drug delivery systems other than gene delivery systems such as exosomes help in avoiding safety and ethical concerns. Within last two decades, the advancements in biomedical sciences have provided promising insights into targets, designing of drugs and other potent therapeutic molecules associated with $\mathrm{AD}$; therefore, search should be continued to produce 'antiamyloid' to combat the progression of AD.

\section{References}

1. Kalaria RN, Maestre GE, Arizaga R, Friedland RP, Galasko D, Hall K, Luchsinger JA, Ogunniyi A, Perry EK, Potocnik F, Prince M. Alzheimers disease and vascular dementia in developing countries: prevalence, management, and risk factors. Lancet Neurology 2008; 7 : 812-826.

2. Leibson CL, Rocca WA, Hanson VA, Cha R, Kokmen E, Obrien PC, Palumbo PJ. Risk of dementia among persons with diabetes mellitus: a population-based cohort study. Am J Epidemiol 1997; 145: 301-308. 
3. Alzheimers Association. 2016 Alzheimers disease facts and figures. Alzheimers Dement 2016; 12: 459-509.

4. Gao S, Hendrie HC, Hall KS, Hui S. The relationships between age, sex, and the incidence of dementia and Alzheimer disease: a meta-analysis. Arc Gene Psych 1998; 55: 809-815.

5. Yaffe K, Sawaya G, Lieberburg I, Grady D. Estrogen therapy in postmenopausal women: effects on cognitive function and dementia. JAMA 1998; 279: 688-695.

6. Grand JH, Caspar S, MacDonald SW. Clinical features and multidisciplinary approaches to dementia care. J Multidiscipl Healthcare 2011; 4: 125.

7. Glenner GG, Wong CW. Alzheimers disease: initial report of the purification and characterization of a novel cerebrovascular amyloid protein. Biochem Biophys Res Commun 1984; 120: 885-890.

8. Rani V, Deshmukh R, Jaswal P, Kumar P, Bariwal J. Alzheimers disease: Is this a brain specific diabetic condition?. Physiol Behav 2016; 164: 259-267.

9. Singh S, Mulley GP, Losowsky MS. Why are Alzheimer patients thin? Age Ageing 1988; 17: 21-28.

10. Faghihi MA, Modarresi F, Khalil AM, Wood DE, Sahagan BG, Morgan TE, Finch CE, St Laurent G 3rd, Kenny PJ, Wahlestedt C. Expression of a noncoding RNA is elevated in Alzheimers disease and drives rapid feed-forward regulation of beta-secretase. Nat Med 2008; 14: 723-730.

11. Delacourte A, Defossez A. Alzheimers disease: Tau proteins, the promoting factors of microtubule assembly, are major components of paired helical filaments. J Neurol Sci 1986; 76: 173-186.

12. Selkoe DJ. Alzheimers disease: genes, proteins, and therapy. Physiol Rev 2001; 81: 741-766.

13. Lovestone S, Reynolds CH, Latimer D, Davis DR, Anderton BH, Gallo JM, Hanger D, Mulot S, Marquardt B, Stabel S, Woodgett JR. Alzheimers disease-like phosphorylation of the microtubule-associated protein tau by glycogen synthase kinase-3 in transfected mammalian cells. Curr Biol 1994; 4: 1077-1086.

14. Brookmeyer R, Johnson E, Ziegler-Graham K, Arrighi HM. Forecasting the global burden of Alzheimers disease. Alzheimers Dement 2007; 3: 186-191.

15. Perry EK, Pickering AT, Wang WW, Houghton PJ, Perry NS. Medicinal plants and Alzheimers disease: from ethnobotany to phytotherapy. J Pharm Pharmacol 1999; 51: 527-534.

16. Park SY, Kim DS. Discovery of natural products from Curcuma longa that protect cells from beta-amyloid insult: a drug discovery effort against Alzheimers disease. J Nat Prod 2002; 65: 1227-1231.

17. Corson TW, Crews CM. Molecular understanding and modern application of traditional medicines: triumphs and trials. Cell 2007; 130: 769-774.

18. Burnside IM. Alzheimers disease: an overview. J Gerontol Nurs 1979; 5: 14-20.

19. Hardy JA1, Higgins GA. Alzheimers disease: the amyloid cascade hypothesis. Science 1992; 256: 184-185.
20. Hurtig HI, Trojanowski JQ, Galvin J, Ewbank D, Schmidt ML, Lee VY, Clark CM, Glosser G, Stern MB, Gollomp SM, Arnold SE. Alpha-synuclein cortical Lewy bodies correlate with dementia in Parkinsons disease. Neurology 2000; 54: 1916-1921.

21. Hendrie HC, Ogunniyi A, Hall KS, Baiyewu O, Unverzagt $\mathrm{FW}$, Gureje $\mathrm{O}$, Gao $\mathrm{S}$, Evans RM, Ogunseyinde AO, Adeyinka AO, Musick B. Incidence of dementia and Alzheimer disease in 2 communities: Yoruba residing in Ibadan, Nigeria, and African Americans residing in Indianapolis, Indiana. JAMA 2001; 285: 739-747.

22. Yan Q, Zhang J, Liu H, Babu-Khan S, Vassar R, Biere AL, Citron M, Landreth G. Anti-inflammatory drug therapy alters beta-amyloid processing and deposition in an animal model of Alzheimers disease. J Neurosci 2003; 23: 7504-7509.

23. Chandra V, Ganguli M, Pandav R, Johnston J, Belle S, DeKosky ST. Prevalence of Alzheimers disease and other dementias in rural India, the Indo-US study. Neurology 1998; 51: 1000-1008.

24. Nitrini R, Caramelli P, Herrera Jr E, Bahia VS, Caixeta LF, Radanovic M, Anghinah R, Charchat-Fichman H, Porto CS, Carthery MT, Hartmann AP. Incidence of dementia in a community-dwelling Brazilian population. Alzheimer Dis Assoc Disord 2004; 18: 241-246.

25. Amemori T, Jendelova P, Ruzicka J, Urdzikova LM, Sykova E. Alzheimers disease: mechanism and approach to cell therapy. Int J Mol Sci 2015; 16: 26417-26451.

26. Bales KR, Verina T, Cummins DJ, Du Y, Dodel RC, Saura J, Fishman CE, DeLong CA, Piccardo P, Petegnief V, Ghetti B. Apolipoprotein E is essential for amyloid deposition in the APPV717F transgenic mouse model of Alzheimers disease. Proc Nat Acad Sci 1999; 96: 15233-15238.

27. Sadowski M, Pankiewicz J, Scholtzova H, Li YS, Quartermain D, Duff K, Wisniewski T. Links between the pathology of Alzheimers disease and vascular dementia. Neurochem Res 2004; 29: 1257-1266.

28. Valente EM, Abou-Sleiman PM, Caputo V, Muqit MM, Harvey K, Gispert S, Ali Z, Del Turco D, Bentivoglio AR, Healy DG, Albanese A, Nussbaum R, GonzálezMaldonado R, Deller T, Salvi S, Cortelli P, Gilks WP, Latchman DS, Harvey RJ, Dallapiccola B, Auburger G, Wood NW. Hereditary early-onset Parkinsons disease caused by mutations in PINK1. Science 2004; 304: 1158-1160.

29. Cherny RA, Atwood CS, Xilinas ME, Gray DN, Jones WD, McLean CA, Barnham KJ, Volitakis I, Fraser FW, Kim YS, Huang X. Treatment with a copper-zinc chelator markedly and rapidly inhibits $\beta$-amyloid accumulation in Alzheimers disease transgenic mice. Neuron 2001; 30: 665-676.

30. Baumann K, Mandelkow EM, Biernat J, Piwnica-Worms H, Mandelkow E. Abnormal Alzheimer-like 
phosphorylation of tau-protein by cyclin-dependent kinases cdk2 and cdk5. FEBS Lett 1993; 336: 417-424.

31. Bramblett GT, Goedert M, Jakes R, Merrick SE, Trojanowski JQ, Lee VM. Abnormal tau phosphorylation at Ser396 in Alzheimers disease recapitulates development and contributes to reduced microtubule binding. Neuron 1993; 10: 1089-1099.

32. Christen Y. Oxidative stress and Alzheimer disease. Am J Clin Nutr 2000; 71: 621-629.

33. Sayre LM, Zelasko DA, Harris PL, Perry G, Salomon RG, Smith MA. 4-hydroxynonenal-derived advanced lipid peroxidation end products are increased in Alzheimers disease. J Neurochem 1997; 68: 2092-2097.

34. Barker SB, Dawson KS. The effects of animal-assisted therapy on anxiety ratings of hospitalized psychiatric patients. Psych Serv 1998; 49: 797-801.

35. Barger SW, Horster D, Furukawa K, Goodman Y, Krieglstein J, Mattson MP. Tumor necrosis factors alpha and beta protect neurons against amyloid beta-peptide toxicity: evidence for involvement of a kappa B-binding factor and attenuation of peroxide and $\mathrm{Ca} 2+$ accumulation. Proc Nat Acad Sci 1995; 92: 9328-9332.

36. Montine TJ, Amarnath V, Martin ME, Strittmatter WJ, Graham DG. E-4-hydroxy-2-nonenal is cytotoxic and cross-links cytoskeletal proteins in P19 neuroglial cultures. Am J Pathol 1996; 148: 89.

37. Calingasan NY, Uchida K, Gibson GE. Protein-bound acrolein: a novel marker of oxidative stress in Alzheimers disease. J Neurochem 1999; 72: 751-756.

38. Friguet B, Szweda LI. Inhibition of the multicatalytic proteinase (proteasome) by 4-hydroxy-2-nonenal crosslinked protein. FEBS Lett 1997; 405: 21-25.

39. Abe T, Tohgi H, Isobe C, Murata T, Sato C. Remarkable increase in the concentration of 8-hydroxyguanosine in cerebrospinal fluid from patients with Alzheimers disease. J Neurosci Res 2002; 70: 447-450.

40. Nunomura A, Perry G, Pappolla MA, Wade R, Hirai K, Chiba S, Smith MA. RNA oxidation is a prominent feature of vulnerable neurons in Alzheimers disease. J Neurosci 1999; 19: 1959-1964.

41. Soto C. Unfolding the role of protein misfolding in neurodegenerative diseases. Nat Rev Neurosci 2003; 4: 49.

42. Chui DH, Dobo E, Makifuchi T, Akiyama H, Kawakatsu S, Petit A, Checler F, Araki W, Takahashi K, Tabira T. Apoptotic neurons in Alzheimers disease frequently show intracellular Abeta42 labeling. J Alzheimers Dis 2001; 3: 231-239.

43. Augustinack JC, Schneider A, Mandelkow EM, Hyman BT. Specific tau phosphorylation sites correlate with severity of neuronal cytopathology in Alzheimers disease. Acta Neuropathologica 2002; 103: 26-35.

44. Kumar-Singh S, Theuns J, Van Broeck B, Pirici D, Vennekens KL, Corsmit E, Cruts M, Dermaut B, Wang R, Van Broeckhoven C. Mean age-of-onset of familial alzheimer disease caused by presenilin mutations correlates with both increased Aß42 and decreased Aß40. Human Mut 2006; 27: 686-695.

45. McGeer PL, McGeer EG. The inflammatory response system of brain: implications for therapy of Alzheimer and other neurodegenerative diseases. Brain Res Rev 1995; 21: 195-218.

46. Ohno M, Sametsky EA, Younkin LH, Oakley H, Younkin SG, Citron M, Vassar R, Disterhoft JF. BACE1 deficiency rescues memory deficits and cholinergic dysfunction in a mouse model of Alzheimers disease. Neuron 2004; 41: 27-33.

47. Selkoe DJ. Alzheimers disease: genes, proteins, and therapy. Physiol Rev 2001; 81: 741-766.

48. Rogaeva E, Meng Y, Lee JH, Gu Y, Kawarai T, Zou F, Katayama T, Baldwin CT, Cheng R, Hasegawa H, Chen F. The neuronal sortilin-related receptor SORL1 is genetically associated with Alzheimer disease. Nat Gene 2007; 39: 168 .

49. Postina R, Schroeder A, Dewachter I, Bohl J, Schmitt U, Kojro E, Prinzen C, Endres K, Hiemke C, Blessing M, Flamez P. A disintegrin-metalloproteinase prevents amyloid plaque formation and hippocampal defects in an Alzheimer disease mouse model. J Clin Investig 2004; 113: $1456-1464$.

50. Rogaeva E, Meng Y, Lee JH, Gu Y, Kawarai T, Zou F, Katayama T, Baldwin CT, Cheng R, Hasegawa H, Chen F. The neuronal sortilin-related receptor SORL1 is genetically associated with Alzheimer disease. Nat Gene 2007; 39: 168 .

51. Mullan M, Crawford F, Axelman K, Houlden H, Lilius L, Winblad B, Lannfelt L. A pathogenic mutation for probable Alzheimers disease in the APP gene at the Nterminus of beta-amyloid. Nat Genet 1992; 1: 345-347.

52. Hutton M, Lendon CL, Rizzu P, Baker M, Froelich S, Houlden H, Pickering-Brown S, Chakraverty S, Isaacs A, Grover A, Hackett J, Adamson J, Lincoln S, Dickson D, Davies P, Petersen RC, Stevens M, de Graaff E, Wauters E, van Baren J, Hillebrand M, Joosse M, Kwon JM, Nowotny P, Che LK, Norton J, Morris JC, Reed LA, Trojanowski J, Basun H, Lannfelt L, Neystat M, Fahn S, Dark F, Tannenberg T, Dodd PR, Hayward N, Kwok JB, Schofield PR, Andreadis A, Snowden J, Craufurd D, Neary D, Owen F, Oostra BA, Hardy J, Goate A, van Swieten J, Mann D, Lynch T, Heutink P. Association of missense and 5-splice-site mutations in tau with the inherited dementia FTDP-17. Nature 1998; 393: 702-705.

53. Kang J, Lemaire HG, Unterbeck A, Salbaum JM, Masters CL, Grzeschik KH, Multhaup G, Beyreuther K, MüllerHill B. The precursor of Alzheimers disease amyloid A4 protein resembles a cell-surface receptor. Nature 1987; 325: 733-736.

54. St George-Hyslop PH, Tanzi RE, Polinsky RJ, Haines JL, Nee L, Watkins PC, Myers RH, Feldman RG, Pollen D, Drachman D. The genetic defect causing familial Alzheimers disease maps on chromosome 21. Science 1987; 235: 885-890. 
55. Citron M, Oltersdorf T, Haass C, McConlogue L, Hung AY, Seubert P, Vigo-Pelfrey C, Lieberburg I, Selkoe DJ. Mutation of the $\beta$-amyloid precursor protein in familial Alzheimers disease increases $\beta$-protein production. Nature. 1992; 360(6405): 672.

56. Jarrett JT, Berger EP, Lansbury PT. The carboxy terminus of the beta. amyloid protein is critical for the seeding of amyloid formation: implications for the pathogenesis of Alzheimers disease. Biochemistry 1993; 32: 4693-4697.

57. Yan SD, Chen X, Fu J, Chen M, Zhu H, Roher A, Slattery T, Zhao L, Nagashima M, Morser J, Migheli A, Nawroth P, Stern D, Schmidt AM. RAGE and amyloid-beta peptide neurotoxicity in Alzheimers disease. Nature 1996; 382: 685-691.

58. Haass C, Lemere CA, Capell A, Citron M, Seubert P, Schenk D, Lannfelt L, Selkoe DJ. The Swedish mutation causes early-onset Alzheimer's disease by $\beta$-secretase cleavage within the secretory pathway. Nat Med 1995; 1 : 1291.

59. Haass C, Selkoe DJ. Cellular processing of beta-amyloid precursor protein and the genesis of amyloid beta-peptide. Cell 1993; 75: 1039-1042.

60. Knops J, Suomensaari S, Lee M, McConlogue L, Seubert $\mathrm{P}$, Sinha S. Cell-type and amyloid precursor protein-type specific inhibition of $A \beta$ release by bafilomycin $A 1$, a selective inhibitor of vacuolar ATPases. J Biol Chem 1995; 270: 2419-2422.

61. Koo EH, Squazzo SL. Evidence that production and release of amyloid beta-protein involves the endocytic pathway. J Biol Chem 1994; 269: 17386-17389.

62. Lemere CA, Munger JS, Shi GP, Natkin L, Haass C, Chapman HA, Selkoe DJ. The lysosomal cysteine protease, cathepsin S, is increased in Alzheimers disease and Down syndrome brain. An immunocytochemical study. Am J Pathol 1995; 146: 848.

63. Scheuner D, Eckman C, Jensen M, Song X, Citron M, Suzuki N, Bird TD, Hardy J, Hutton M, Kukull W, Larson E. Secreted amyloid $\beta$-protein similar to that in the senile plaques of Alzheimers disease is increased in vivo by the presenilin 1 and 2 and APP mutations linked to familial Alzheimers disease. Nat Med 1996; 2: 864.

64. Roher AE, Lowenson JD, Clarke S, Wolkow C, Wang RO, Cotter RJ, Reardon IM, Zürcher-Neely HA, Heinrikson RL, Ball MJ. Structural alterations in the peptide backbone of beta-amyloid core protein may account for its deposition and stability in Alzheimers disease. J Biol Chem 1993; 268: 3072-3083.

65. Haass C, Koo EH, Mellon A, Hung AY, Selkoe DJ. Targeting of cell-surface $\beta$-amyloid precursor protein to lysosomes: alternative processing into amyloid-bearing fragments. Nature 1992; 357: 500.

66. Selkoe DJ, Yamazaki T, Citron M, Podlisny MB, Koo EH, Teplow DB, Haass C. The role of APP processing and trafficking pathways in the formation of amyloid betaprotein. Ann N Y Acad Sci 1996; 777: 57-64.
67. $\mathrm{Xu} \mathrm{H}$, Gouras GK, Greenfield JP, Vincent B, Naslund J, Mazzarelli L, Fried G, Jovanovic JN, Seeger M, Relkin NR, Liao F. Estrogen reduces neuronal generation of Alzheimer $\beta$-amyloid peptides. Nat Med 1998; 4: 447.

68. Hooper C, Killick R, Lovestone S. The GSK3 hypothesis of Alzheimers disease. J Neurochem 2008; 104: 1433-1439.

69. Takashima A, Noguchi K, Michel G, Mercken M, Hoshi $\mathrm{M}$, Ishiguro $\mathrm{K}$, Imahori K. Exposure of rat hippocampal neurons to amyloid $\beta$ peptide (25-35) induces the inactivation of phosphatidyl inositol-3 kinase and the activation of tau protein kinase I/glycogen synthase kinase-3ß. Neurosci Lett 1996; 203: 33-36.

70. Turenne GA, Price BD. Glycogen synthase kinase 3 beta phosphorylates serine 33 of $\mathrm{p} 53$ and activates $\mathrm{p} 53 \mathrm{~s}$ transcriptional activity. BMC Cell Biol 2001; 2: 12.

71. Lemere CA, Lopera F, Kosik KS, Lendon CL, Ossa J, Saido TC, Yamaguchi H, Ruiz A, Martinez A, Madrigal L, Hincapie L. The E280A presenilin 1 Alzheimer mutation produces increased A $\beta 42$ deposition and severe cerebellar pathology. Nat Med 1996; 2: 1146.

72. Imahori K, Uchida T. Physiology and pathology of tau protein kinases in relation to Alzheimers disease. J Biochem 1997; 121: 179-188.

73. Pei JJ, Tanaka T, Tung YC, Braak E, Iqbal K, GrundkeIqbal I. Distribution, levels, and activity of glycogen synthase kinase-3 in the Alzheimer disease brain. J Neuropathol Exp Neurol 1997; 56: 70-78.

74. Lu PJ, Wulf G, Zhou XZ, Davies P, Lu KP. The prolyl isomerase Pin1 restores the function of Alzheimerassociated phosphorylated tau protein. Nature 1999; 399: 784.

75. Lippens G, Sillen A, Landrieu I, Amniai L, Sibille N, Barbier P, Leroy A, Hanoulle X, Wieruszeski JM. Tau aggregation in Alzheimers disease: what role for phosphorylation? Prion 2007; 1: 21-25.

76. Blalock EM, Geddes JW, Chen KC, Porter NM, Markesbery WR, Landfield PW. Incipient Alzheimers disease: microarray correlation analyses reveal major transcriptional and tumor suppressor responses. Proc Nat Acad Sci 2004; 101: 2173-2178.

77. Hye A, Lynham S, Thambisetty M, Causevic M, Campbell J, Byers HL, Hooper C, Rijsdijk F, Tabrizi SJ, Banner S, Shaw CE, Foy C, Poppe M, Archer N, Hamilton G, Powell J, Brown RG, Sham P, Ward M, Lovestone S. Proteome-based plasma biomarkers for Alzheimers disease. Brain 2006; 129: 3042-3050.

78. Rodríguez E, Mateo I, Infante J, Llorca J, Berciano J, Combarros O. Cholesteryl ester transfer protein (CETP) polymorphism modifies the Alzheimers disease risk associated with APOE e4 allele. J Neurol 2006; 253: 181-185.

79. Pei JJ, Tanaka T, Tung YC, Braak E, Iqbal K, GrundkeIqbal I. Distribution, levels, and activity of glycogen synthase kinase-3 in the Alzheimer disease brain. J Neuropathol Exp Neurol 1997; 56: 70-78. 
80. Swatton JE, Sellers LA, Faull RL, Holland A, Iritani S, Bahn S. Increased MAP kinase activity in Alzheimers and Down syndrome but not in schizophrenia human brain. Eur J Neurosci 2004; 19: 2711-2719.

81. De Ferrari GV, Papassotiropoulos A, Biechele T, DeVrieze FW, Avila ME, Major MB, Myers A, Saez K, Henríquez JP, Zhao A, Wollmer MA. Common genetic variation within the low-density lipoprotein receptorrelated protein 6 and late-onset Alzheimer's disease. Proc Nat Acad Sci 2007; 104: 9434-9439.

82. Biessels GJ, Kappelle LJ. Increased risk of Alzheimers disease in type II diabetes: insulin resistance of the brain or insulin-induced amyloid pathology? Biochem Soc Trans 2005; 33: 1041-1044.

83. Hamilton G, Proitsi P, Jehu L, Morgan A, Williams J, ODonovan MC, Owen MJ, Powell JF, Lovestone S. Candidate gene association study of insulin signaling genes and Alzheimers disease: evidence for SOS2, PCK1, and PPAR $\gamma$ as susceptibility loci. Am J Med Genet B Neuropsych Genet 2007; 144: 508-516.

84. Reiman EM. Linking brain imaging and genomics in the study of Alzheimers disease and aging. Ann N Y Acad Sci 2007; 1097: 94-113.

85. Holmans P, Hamshere M, Hollingworth P, Rice F, Tunstall N, Jones S, Moore P, DeVrieze FW, Myers A, Crook R, Compton D. Genome screen for loci influencing age at onset and rate of decline in late onset Alzheimer's disease. Am J Med Genet B Neuropsych Genet 2005; 135: 24-32.

86. Perry T, Greig NH. Enhancing central nervous system endogenous GLP-1 receptor pathways for intervention in Alzheimers disease. Curr Alzheimer Res 2005; 2: 377-385.

87. Choudhury A, Sahu T, Ramanujam PL, Banerjee AK, Chakraborty I, Kumar AR, Arora N. Neurochemicals, behaviours and psychiatric perspectives of neurological diseases. Neuropsychiatry (London) 2018; 8: 395-424.

88. Mesulam M. The cholinergic lesion of Alzheimers disease: pivotal factor or side show? Learn Mem 2004; 11: 43-49.

89. Mueller BK, Mack H, Teusch N. Rho kinase, a promising drug target for neurological disorders. Nat Rev Drug Discov 2005; 4: 387-398.

90. Hoffmann C, Pop M, Leemhuis J, Schirmer J, Aktories K, Schmidt G. The Yersinia pseudotuberculosis Cytotoxic Necrotizing Factor (CNFY) selectively activates RhoA. J Biol Chem 2004; 279: 16026-16032.

91. Panyam J, Williams D, Dash A, Leslie-Pelecky D, Labhasetwar V. Solid-state solubility influences encapsulation and release of hydrophobic drugs from PLGA/PLA nanoparticles. J Pharm Sci 2004; 93: 1804-1814.

92. Wu YH, Feenstra MG, Zhou JN, Liu RY, Torano JS, Van Kan HJ, Fischer DF, Ravid R, Swaab DF. Molecular changes underlying reduced pineal melatonin levels in Alzheimer disease: alterations in preclinical and clinical stages. J Clin Endocrinol Metabol 2003; 88: 5898-5906.
93. Nagahama Y, Nabatame H, Okina T, Yamauchi H, Narita M, Fujimoto N, Murakami M, Fukuyama H, Matsuda M. Cerebral correlates of the progression rate of the cognitive decline in probable Alzheimers disease. Eur Neurol 2003; 50: $1-9$.

94. Oakley H, Cole SL, Logan S, Maus E, Shao P, Craft J, Guillozet-Bongaarts A, Ohno M, Disterhoft J, Van Eldik L, Berry R. Intraneuronal $\beta$-amyloid aggregates, neurodegeneration, and neuron loss in transgenic mice with five familial Alzheimers disease mutations: potential factors in amyloid plaque formation. J Neurosci 2006; 26 : 10129-10140.

95. Pedrini S, Carter TL, Prendergast G, Petanceska S, Ehrlich ME, Gandy S. Modulation of statin-activated shedding of Alzheimer APP ectodomain by ROCK. PLoS Med 2005; 2: 18.

96. Ostrowski SM, Wilkinson BL, Golde TE, Landreth G. Statins reduce amyloid- $\beta$ production through inhibition of protein isoprenylation. J Biol Chem 2007; 282: 26832-26844.

97. Salminen A, Suuronen T, Kaarniranta K. ROCK, PAK, and toll of synapses in Alzheimers disease. Biochem Biophys Res Commun 2008; 371: 587-590.

98. Missiaen L, Taylor CW, Berridge MJ. Spontaneous calcium release from inositol trisphosphate-sensitive calcium stores. Nature 1991; 352: 241.

99. Toide K, Okamiya K, Iwamoto Y, Kato T. Effect of a novel prolyl endopeptidase inhibitor, JTP-4819, on prolyl endopeptidase activity and substance P-and argininevasopressin-like immunoreactivity in the brains of aged rats. J Neurochem 1995; 65: 234-240.

100. Krausz Y, Bonne O, Gorfine M, Karger H, Lerer B, Chisin R. Age-related changes in brain perfusion of normal subjects detected by $99 \mathrm{~m}$ Tc-HMPAO SPECT. Neuroradiology 1998; 40: 428-434.

101. De Nanteuil G, Portevin B, Lepagnol J. Prolyl endopeptidase inhibitors: a new class of memory enhancing drugs. Drugs Future 1998; 23: 167-180.

102. Toide K, Shinoda M, Iwamoto Y, Fujiwara T, Okamiya K, Uemura A. A novel prolyl endopeptidase inhibitor, JTP-4819, with potential for treating Alzheimers disease. Behav Brain Res 1997; 83: 147-151.

103. Chen R, Zhang J, Wu Y, Wang D, Feng G, Tang YP, Teng $\mathrm{Z}$, Chen C. Monoacylglycerol lipase is a therapeutic target for Alzheimers disease. Cell Rep 2012; 2: 1329-1339.

104. Pazos MR, Nunez E, Benito C, Tolón RM, Romero J. Role of the endocannabinoid system in Alzheimers disease: new perspectives. Life Sci 2004; 75: 1907-1915.

105. Brookmeyer R, Johnson E, Ziegler-Graham K, Arrighi HM. Forecasting the global burden of Alzheimers disease. Alzheimers Dement 2007; 3: 186-191.

106. Cross AJ, Crow TJ, Perry EK, Perry RH, Blessed G, Tomlinson BE. Reduced dopamine-beta-hydroxylase activity in Alzheimers disease. Br Med J (Clin Res Edn.) 1981; 282: 93. 
107. Saura JL, Luque JM, Cesura AM, Da Prada M, ChanPalay V, Huber G, Löffler J, Richards JG. Increased monoamine oxidase $\mathrm{B}$ activity in plaque-associated astrocytes of Alzheimer brains revealed by quantitative enzyme radioautography. Neuroscience 1994; 62: 15-30.

108. Zhao L, Brinton RD. Structure-based virtual screening for plant-based ER $\beta$-selective ligands as potential preventative therapy against age-related neurodegenerative diseases. J Med Chem 2005; 48: 3463-3466.

109. Borah A, Choudhury A, Paul R, Mazumder MK, Chetia S. Neuroprotective effect of ayurvedic preparations and natural products on Parkinsons disease. Neuroprotect Nat Prod Clin Aspect Mod Act 2017.

110. Bacanu SA, Devlin B, Chowdari KV, DeKosky ST, Nimgaonkar VL, Sweet RA. Heritability of psychosis in Alzheimer disease. Am J Geriatr Psychiatry 2005; 13: 624-627.

111. Kumar-Singh S, Theuns J, Van Broeck B, Pirici D, Vennekens KL, Corsmit E, Cruts M, Dermaut B, Wang R, Van Broeckhoven C. Mean age-of-onset of familial alzheimer disease caused by presenilin mutations correlates with both increased $\mathrm{A} \beta 42$ and decreased $\mathrm{A} \beta 40$. Human Mut 2006; 27: 686-695.

112. Vinutha B, Prashanth D, Salma K, Sreeja SL, Pratiti D, Padmaja R, Radhika S, Amit A, Venkateshwarlu K, Deepak M. Screening of selected Indian medicinal plants for acetylcholinesterase inhibitory activity. J Ethnopharmacol 2007; 109: 359-363.

113. Scheuner D, Eckman C, Jensen M, Song X, Citron M, Suzuki N, Bird TD, Hardy J, Hutton M, Kukull W, Larson E. Secreted amyloid $\beta$-protein similar to that in the senile plaques of Alzheimers disease is increased in vivo by the presenilin 1 and 2 and APP mutations linked to familial Alzheimers disease. Nat Med 1996; 2: 864.

114. Hsiao KK, Borchelt DR, Olson K, Johannsdottir R, Kitt C, Yunis W, Xu S, Eckman C, Younkin S, Price D, Iadecola C. Age-related CNS disorder and early death in transgenic $\mathrm{FVB} / \mathrm{N}$ mice overexpressing Alzheimer amyloid precursor proteins. Neuron 1995; 15: 1203-1218.

115. Li SJ, Li Z, Wu G, Zhang MJ, Franczak M, Antuono PG. Alzheimer disease: evaluation of a functional MR imaging index as a marker. Radiology 2002; 225: 253-259.
116. Blacker D, Wilcox MA, Laird NM, Rodes L, Horvath SM, Go RC, Perry R, Watson Jr B, Bassett SS, McInnis MG, Albert MS. Alpha-2 macroglobulin is genetically associated with Alzheimer disease. Nat Genet 1998; 19: 357.

117. Perry RJ, Hodges JR. Attention and executive deficits in Alzheimers disease. A critical review. Brain 1999; 122: 383-404.

118. Danysz W, Parsons CG. The NMDA receptor antagonist memantine as a symptomatological and neuroprotective treatment for Alzheimers disease: preclinical evidence. Int J Geriatr Psych 2003; 18.

119. Mograbi DC, Brown RG, Salas C, Morris RG. Emotional reactivity and awareness of task performance in Alzheimers disease. Neuropsychologia 2012; 50: 2075-2084.

120. Scharf S, Mander A, Ugoni A, Vajda F, Christophidis N. A double-blind, placebo-controlled trial of diclofenac/ misoprostol in Alzheimers disease. Neurology 1999; 53: 197.

121. Reines SA, Block GA, Morris JC, Liu G, Nessly ML, Lines CR, Norman BA, Baranak CC, Rofecoxib Protocol 091 Study Group. Rofecoxib no effect on Alzheimers disease in a 1-year, randomized, blinded, controlled study. Neurology 2004; 62: 66-71.

122. Aisen PS, Schafer KA, Grundman M, Pfeiffer E, Sano M, Davis KL, Farlow MR, Jin S, Thomas RG, Thal LJ, Alzheimers Disease Cooperative Study. Effects of rofecoxib or naproxen vs. placebo on Alzheimer disease progression: a randomized controlled trial. JAMA 2003; 289: 2819-2826.

\section{*Correspondence to}

Amarendranath Choudhury, Ph.D.

Ganapathi Enclave

Singapore City Road

Vizianagaram, Visakhapatnam

India 